\title{
HARGA DAN PROSES TERHADAP KEPUASAN KONSUMEN KAFE INSTAMIE DI KOTA BANDUNG
}

\author{
Popo Suryana \\ popo_suryana@unpas.ac.id \\ Intan Muliasari \\ Fakultas Ekonomi dan Bisnis - Universitas Pasundan
}

diterima: 28/11/2017; direvisi: 19/1/2018; diterbitkan: 24/2/2018

\begin{abstract}
The study aims to determine the influence of price and process on customer satisfaction at Instamie Cafe in Bandung either simultaneously or partially. The research method used is descriptive and verificative with sample size of 100 respondents. Data collection techniques used were observation, interview and questionnaire distribution. Data analysis method used is multiple linear regression, multiple correlation and coefficient of determination. The result shows that price of Instamie Cafe was too expensive and less service process and customer did not satisfy. Price and service process contribute to consumer satisfaction at Instamie Cafe. Based on the coefficient of partial determination, this study shows that the process gives greater influence on customer satisfaction than price.
\end{abstract}

Keywords: price; process; consumer satisfaction

\begin{abstract}
Abstrak
Penelitian bertujuan untuk mengetahui pengaruh harga dan proses terhadap kepuasan konsumen pada Kafe Instamie di kota Bandung baik secara simultan maupun parsial. Metode penelitian yang digunakan adalah deskriptif dan verifikatif dengan ukuran sampel sebanyak 100 responden. Teknik pengumpulan data yang digunakan adalah observasi, wawancara, dan penyebaran kuesioner dengan metode analisis regresi linier berganda, korelasi ganda, dan koefisien determinasi. Hasil penelitian menunjukkan harga kurang terjangkau, dan proses pelayanan kurang baik, serta konsumen dipersepsikan tidak puas. Berdasarkan analisis koefisien determinasi menunjukkan bahwa harga dan proses pelayanan berpengaruh terhadap kepuasan konsumen pada Kafe Instamie. Secara parsial proses pelayanan memberikan pengaruh yang lebih dominan terhadap kepuasan konsumen daripada harga.
\end{abstract}

Kata Kunci : harga; proses; kepuasan konsumen 


\section{PENDAHULUAN}

Persaingan bisnis merupakan fenomena yang sangat menarik untuk diteliti, terlebih di era globalisasi dalam bidang ekonomi yang semakin terbuka. Hal ini turut membuka peluang bagi setiap perusahaan untuk berkompetisi menjaring konsumen. Perusahaan dituntut bekerja keras untuk memberikan barang atau jasa yang terbaik untuk memenuhi keinginan dan kebutuhan yang sesuai dengan harapan konsumen. Persaingan bisnis di Indonesia, tidak terlepas dari campur tangan pariwisata, karena di Indonesia sendiri memiliki banyak kota atau daerah wisata. Potensi wisata suatu daerah atau kota menjadi faktor penting dalam perekonomian daerah atau kota itu sendiri, sehingga persaingan bagi setiap perusahaan penyedia barang atau jasa dan masyarakat berusaha untuk mendapatkan ekonomi yang lebih baik melalui perkembangan pariwisata.

Kota Bandung merupakan salah satu kota yang menjadi pilihan destinasi untuk berwisata. Letak wilayahnya yang cukup strategis $140 \mathrm{Km}$ sebelah tenggara Jakarta menjadikan Kota Bandung pilihan destinasi wisata yang menarik untuk di kunjungi oleh para wisatawan lokal maupun wisatawan mancanegara. Pada tahun 1920-an Kota Bandung mendapat julukan Paris van Java. Julukan ini diperkenalkan oleh warga Eropa yang bermukim di Kota Bandung. Julukan ini semakin lama semakin dikenal oleh banyak orang yang beranggapan bahwa Kota Bandung merupakan kota Fashion seperti Paris, sehingga julukan ini mengundang perhatian para wisatawan lokal maupun mancanegara untuk berkunjung ke Kota Bandung. Selain dikenal dengan Paris Van Java, Kota Bandung juga dikenal sebagai Kota Kembang. Julukan ini mengisyaratkan bahwa Kota Bandung merupakan kota yang indah dan sejuk. Keindahan Bandung diisyaratkan seperti bunga, sedangkan kesejukan Kota Bandung disebabkan karena banyaknya pepohonan yang tumbuh di Kota Bandung. Kesejukan dan keindahan alam Kota Bandung salah satunya lembang menjadi daya tarik tersendiri bagi para wisatawan untuk berkunjung ke Kota Bandung.

Wisata kuliner tidak kalah ramainya dengan wisata lain yang ada di Kota Bandung. Berbagai macam inovasi dan kreatifitas olahan makanan di Kota Bandung sudah tidak diragukan lagi. Kota Ini menawarkan beraneka ragam olahan makanan yang mempunyai cita rasa tradisional maupun internasional. Keaneka ragaman dan keunikan cita rasa kuliner di Kota Bandung menjadi daya tarik tersendiri untuk mengundang para wisatwan baik lokal maupun mancanegara untuk berkunjung ke
Kota Bandung. Pertumbuhan ekonomi masyarakat yang semakin bertambah berdampak pada semakin bertambah pula aneka ragam kebutuhan barang dan jasa untuk memenuhi kebutuhan dan memuaskan keinginan konsumen. Perusahaan sebagai penghasil produk barang dan jasa memiliki peranan yang penting dalam memenuhi kebutuhan yang sesuai dengan perkembangan teknologi.

Berikut perkembangan industri Kafe sebagai penyedia makanan dan minuman di Kota Bandung dari tahun 2010 sampai tahun 2014.

Tabel 1. Perkembangan Industri Kafe dan Resto di Kota Bandung

\begin{tabular}{ccc}
\hline Tahun & Jumlah Kafe & Persentase Kenaikan \\
\hline 2010 & 191 & $2,68 \%$ \\
2011 & 196 & $2,61 \%$ \\
2012 & 235 & $19,89 \%$ \\
2013 & 432 & $49,8 \%$ \\
2014 & 653 & $51,2 \%$ \\
\hline
\end{tabular}

Sumber : Kota Bandung Dalam Angka, 2015 (Bandungkota.bps. go.id)

Tabel 1 menunjukkan perkembangan industri kafe dan resto di Kota Bandung dari tahun 2010 sampai dengan tahun 2014. Pada tahun 2010 jumlah kafe yang ada di Bandung berjumlah paling sedikit dibanding dengan tahun mendatang. Pada tahun 2010, hanya terdapat 191 kafe yang berada di Kota Bandung dengan persentase kenaikan sebesar 2,68\%. Pada tahun 2011 jumlah kafe di Kota Bandung terlihat meningkat namun peningkatan tersebut tidak signifikan karena hanya mengalami peningkatan sebesar 2,61\% sehingga pada tahun 2011 jumlah kafe yang ada di Bandung bertambah sebanyak 196 kafe. Pada tahun 2012, peningkatan jumlah kafe mulai menunjukan kenaikan yang cukup signifikan yakni mengalami peningkatan persentase sebesar 19,89\% sehingga peningkatan jumlah kafe di Kota Bandung bertambah menjadi sebanyak 235 kafe. Peningkatan yang cukup signifikan terjadi pada tahun 2013, dimana persentase peningkatan jumlah kafe mencapai 49,8 $\%$, peningkatan jumlah kafe pada tahun 2013 di Kota Bandung bertambah menjadi sebanyak 432 kafe. Peningkatan tertinggi jumlah kafe yang ada di Kota Bandung terjadi pada tahun 2014 dengan peningkatan presentase yang paling besar dibandingkan dengan tahun-tahun sebelumnya. Presentasi kenaikan jumlah kafe sebesar 51,2\% dengan jumlah kafe bertambah menjadi sebanyak 653 kafe.

Tabel 2 menunjukkan perkiraan atau peramalan jumlah kafe dan resto di Kota Bandung 5 tahun mendatang yang setiap tahunnya akan terus mengalami peningkatan cukup signifikan. 
Tabel 2. Perkiraan Jumlah Kafe dan Resto di Kota Bandung 5 Tahun Mendatang

\begin{tabular}{ccc}
\hline Tahun & Jumlah Kafe dan Resto & Persentase Kenaikan \\
\hline 2015 & 689 & $5,5 \%$ \\
2016 & 805 & $16,83 \%$ \\
2017 & 921 & \\
2018 & 1037 & \\
2019 & 1153 & \\
\hline Sumber : hasil pengolahan penulis, 2016
\end{tabular}

Kafe Instamie yang berlokasi di Jl. Tamansari Kota Bandung merupakan salah satu kafe yang ikut meramaikan industri kuliner di Kota Bandung. Kafe Instamie menyediakan berbagai produk makanan yang variatif dengan citarasa western seperti rice bowl. Produk yang menjadi unggulan Kafe Instamie yaitu produk makanan yang berbahan dasar Mie. Berbagai produk dengan bahan dasar mie banyak disediakan oleh Kafe Instamie, salah satunya adalah tom yum. tom yum di Kafe Instamie memiliki rasa yang unik dan berbeda dengan tom yum di tempat lain. Seiring dengan berkembangnya bisnis Kafe Instamie dengan produk unggulan berbahan dasar mie, belum tentu tidak mempunyai pesaing. Saat ini banyak kafe-kafe sejenis yang bermunculan. Hal tersebut tentu menjadi ancaman tersendiri bagi Kafe Instamie Bandung dalam kelangsungan usahanya. Dibutuhkan strategi-strategi pemasaran yang baik agar dapat bersaing dengan pebisnis kuliner lain agar mampu bertahan di pasaran.

Tabel 3. Beberapa Kafe Sejenis di Kota Bandung

\begin{tabular}{cll}
\hline No & \multicolumn{1}{c}{ Nama Kafe } & \multicolumn{1}{c}{ Alamat } \\
\hline 1 & UP Normal & Jl.Cihampelas 56A \\
2 & Kafe Madtari & Jl. Rangga Gading No. 12 Bandung \\
3 & Kafe JKT 66 & J1.Terusan Jakarta No. 66 Bandung \\
4 & Kafe Instamie & Jl. Tamansari No \\
5 & Mie Siga Pisan & Jl. PHH Mustofa No. 100 Bandung \\
6 & What's Up Cafe & Jl. Burangrang No. 37 Lengkong, \\
\hline
\end{tabular}

Sumber: www.infobdg.com

Tabel 3 menunjukkan beberapa kafe sejenis yang ada di Kota Bandung yang menjadi pesaing bagi Kafe Instamie Bandung. Semakin ketatnya iklim persaingan menyebabkan Kafe Instamie Bandung harus berusaha keras untuk tetap dapat bertahan dengan cara terus melakukan beberapa perbaikan baik dari produk, harga, tempat, promosi, orang, proses dan fasilitas fisik. Banyaknya usaha sejenis yang menyebabkan persiangan antar kafe yang semakin ketat, maka penulis tertarik untuk melakukan wawancara kepada supervisor Kafe Instamie mengenai jumlah konsumen yang berkunjung ke Kafe Instamie selama 3 Triwulan Tahun 2016. Perkembangan jumlah pengunjung Kafe Instamie Bandung berdasarkan hasil wawancara dengan Supervisor Kafe Instamie Bandung ditunjukkan pada Tabel 4.
Tabel 4. Jumlah Pengunjung Kafe Instamie Bandung 3 Triwulan Tahun 2016

\begin{tabular}{llcc}
\hline Triwulan & Bulan & $\begin{array}{c}\text { Jumlah Pengunjung } \\
\text { (orang) }\end{array}$ & Keterangan \\
\hline Triwulan 1 & Januari & 2200 & - \\
& Februari & 2590 & +390 \\
& Maret & 2430 & -160 \\
Triwulan 2 & April & 2320 & -110 \\
& Mei & 1980 & -340 \\
\hline \multirow{2}{*}{ Triwulan 3 } & Juni & 2110 & +130 \\
& Agustus & 2600 & +490 \\
& September & 2470 & -130 \\
\hline
\end{tabular}

Sumber : Kafe Instamie Bandung

Tabel 4 menunjukkan perkembangan jumlah pengunjung Kafe Instamie Bandung. Pada triwulan ke-1, dari bulan Januari sampai bulan Februari jumlah pengunjung mengalami peningkatan sebanyak 390 orang. Namun pada bulan Maret jumlah pengunjung mengalami penurunan sebanyak 160 orang dari bulan sebelumnya. Pada triwulan Ke-2, jumlah pengunjung Kafe Instamie dari bulan April ke Mei mengalami penurunan sebanyak 340 orang. Namun pada bulan Juni jumlah pengunjung Kafe Instamie mengalami peningkatan kembali dari bulan sebelumnya sebanyak 130 orang. Selanjutnya pada triwulan ke-3 Kafe Instamie selama 2 bulan berturut-turut terus mengalami penurunan jumlah pengunjung. Dari bulan Juli ke Agustus terjadi penurunan jumlah pengunjung sebanyak 130 orang, dan hal yang sama juga terjadi pada bulan September yang mengalami penurunan jumlah pengunjung dari bulan bulan sebelumnya sebanyak 320 orang. Berdasarkan hasil wawancara diperoleh bahwa pada triwulan ke -1 dan ke -2 jumlah pengunjung Kafe Instamie berfluktuasi, sedangkan pada triwulan ke -3 cenderung menurun. Data penjualan Kafe Instamie Bandung diperoleh dari hasil wawancara dengan supervisor ditunjukkan pada Tabel 5.

Tabel 5. Data Penjualan Kafe Instamie Bandung Triwulan 1, Triwulan 2 dan Triwulan 3 Tahun 2016

\begin{tabular}{clcc}
\hline Triwulan & Bulan & Pendapatan(Rupiah) & Keterangan \\
\hline Triwulan 1 & Januari & Rp. 153.000.000 & - \\
& Februari & Rp. 172.000.000 & +19.000 .000 \\
& Maret & Rp. 167.000.000 & -5.000 .000 \\
Triwulan 2 & April & Rp. 159.000.000 & -8.000 .000 \\
& Mei & Rp. 141.000.000 & -18.000 .000 \\
& Juni & Rp. 150.000.000 & +9.000 .000 \\
Triwulan 3 & Juli & Rp. 171.000.000 & +21.000 .000 \\
& Agustus & Rp. 163.000 .000 & -8.000 .000 \\
& September & Rp. 152.000.000 & -11.000 .000 \\
\hline
\end{tabular}

Sumber : Kafe Instamie Bandung 
Tabel 6 menunjukkan berbagai keluhan yang dirasakan konsumen Kafe Instamie Bandung.

Tabel 6. Keluhan Konsumen pada Kafe Instamie Bandung

\begin{tabular}{ll}
\hline No & \multicolumn{1}{c}{ Keluhan } \\
\hline 1 & Harga tergolong mahal \\
2 & Tidak tersedia kursi sandar didalam kafe \\
3 & Proses pemesanan sampai penyajian terkadang lama \\
4 & Area parkir tidak memadai \\
\hline Sumber : Kafe Instamie Bandung
\end{tabular}

Konsumen mengeluhkan harga yang relatif mahal namun tidak sesuai dengan kualitas yang dirasakan. Selain itu fasilitas fisik seperti kursi yang dinilai kurang lengkap yaitu tidak adanya kursi sandar di Kafe Instamie karena kenyataannya Kafe Instamie memang hanya menyediakan kursi biasa yang tanpa sandaran sehingga konsumen merasa kurang nyaman dan kurang merasa santai berada di Kafe Instamie. Konsumen Kafe Instamie juga mengeluhkan lamanya penyajian makanan dan minuman yang dipesan konsumen, hal ini sangat membuat konsumen merasa kecewa dan kesal karena harus menunggu hidangan makanan dan minuman dalam waktu yang lama. Selain itu tempat parkir yang tidak luas juga dianggap kurang luas menurut konsumen Kafe Instamie Bandung, terkadang konsumen tidak jadi membeli atau masuk ke Kafe Instamie Bandung karena lahan parkir yang sempit dan penuh.

Berdasarkan latar belakang mengenai fenomena kepuasan konsumen dan faktor-faktor yang mempengaruhinya pada Kafe Instamie Bandung, melalui hasil penelitian pendahuluan dapat diidentifikasi masalah sebagai berikut: (1) Terdapat beberapa kafe yang sejenis sehingga menambah persaingan yang semakin ketat; (2) Berdasarkan hasil wawancara Jumlah pengunjung Kafe Instamie pada Triwulan ke-1 dan Triwulan ke-2 tahun 2016 mengalami fluktuatif dan pada Triwulan ke-3 tahun 2016 mengalami penurunan; (3) Berdasarkan hasil wawancara pendapatan Kafe Instamie pada Triwulan ke-1 dan Triwulan ke-2 tahun 2016 mengalami fluktuatif dan pada Triwulan ke-3 tahun 2016 mengalami penurunan; (4) Terdapat keluhan-keluhan dari konsumen terhadap Kafe Instamie; (5) Hasil penelitian pendahuluan menunjukan bahwa harga produk di Kafe Instamie dinilai kurang terjangkau; (6) Hasil penelitian pendahuluan menunjukan bahwa proses penyajian produk di Kafe Instamie dinilai lama; (7) Hasil penelitian pendahuluan menunjukan bahwa kepuasan konsumen terhadap Kafe Instamie masih rendah.

\section{Kepuasan Konsumen}

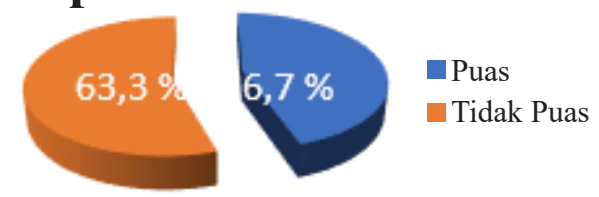

Sumber: Hasil Pengolahan Penulis,2016

Gambar 1. Hasil Penelitian pendahuluan Mengenai Kepuasan Konsumen Pada Kafe Instamie Bandung

Berdasarkan Gambar 1, mengenai kepuasan konsumen pada Kafe Instamie Bandung menyatakan bahwa dari 30 responden, sebanyak $36,7 \%$ konsumen menyatakan merasa puas terhadap Kafe Instamie Bandung. Sementara sebanyak 63,3\% menyatakan bahwa konsumen merasa tidak puas terhadap Kafe Instamie Bandung. Maka penulis dapat menyimpulkan bahwa kepuasan konsumen terhadap Kafe Instamie masih sangat rendah.

Kepuasan menjadi prioritas utama bagi konsumen dan perusahaan. Konsumen selalu ingin merasakan kepuasan dari produk yang ia beli begitupun dengan perusahaan ingin memberikan kepuasan kepada konsumen agar konsumen tetap membeli produk yang ditawarkan oleh perusahaan. Kepuasan konsumen sangat berpengaruh bagi keberlangsungan, perkembangan dan kesuksesan perusahaan itu sendiri sehingga saat ini banyak perusahaan yang memahami arti penting dari kepuasan dan berusaha untuk menerapkan strategistrategi pemasaran yang baik dan tepat guna memperoleh kepuasan dari konsumennya.

Kepuasan konsumen berkontribusi besar pada sejumlah aspek krusial seperti terciptanya loyalitas konsumen tehadap produk atau jasa yang ditawarkan oleh perusahaan, terciptanya reputasi perusahaan yang baik yang baik apabila konsumen merasa puas dan berkurangnya elastisitas harga. Disamping itu, kepuasan juga merupakan salah satu indikator yang penting untuk keberlangsungan perusahaan di masa depan. Apabila konsumen merasa puas banyak keuntungankeuntungan yang akan didapatkan oleh perusahaan karena konsumen yang merasa puas biasanya akan melukan pembelian ulang, merekomendasikan produk atau jasa yang dibelinya kepada oranglain, dan membeli lini produk yang lain. Berbeda halnya dengan konsumen yang merasa tidak puas, biasanya konsumen akan mempertimbangkan untuk membeli kembali produk atau jasa tersebut.

Berdasarkan pada fenomena adanya rendahnya kepuasan konsumen terhadap Kafe Instamie Bandung, maka penulis melakukan penelitian pendahuluan kepada konsumen Kafe Instamie Bandung sebanyak 
Tabel 7. Hasil Penelitian pendahuluan Mengenai Faktor-faktor yang Mempengaruhi Kepuasan Konsumen Pada Kafe Instamie Bandung

\begin{tabular}{|c|c|c|c|c|c|c|c|c|}
\hline \multirow{2}{*}{ No } & \multirow{2}{*}{ Dimensi } & \multirow{2}{*}{ Pernyataan } & \multicolumn{6}{|c|}{ Alternatif Jawaban } \\
\hline & & & SS & $\mathrm{S}$ & $\mathrm{CS}$ & $\mathrm{TS}$ & STS & TOTAL \\
\hline \multirow[t]{2}{*}{1} & Produk & Makanan dan minuman yang ditawarkan sangat beraneka ragam & 13,3 & 66,7 & 20 & 0 & 0 & 100 \\
\hline & & Makanan dan minuman yang ditawarkan sangat menarik perhatian anda & 10 & 53,3 & 33,3 & 3,3 & 0 & 100 \\
\hline \multirow[t]{2}{*}{2} & Harga & Harga makanan dan minuman sangat murah dan terjangkau & 10 & 23,3 & 60 & 6,7 & 0 & 100 \\
\hline & & Harga makanan dan minuman sangat sesuai dengan kualitasnya & 10 & 33,3 & 46,7 & 10 & 0 & 100 \\
\hline \multirow[t]{2}{*}{3} & Tempat & Lokasi Kafe Instamie Bandung sangat strategis & 26,7 & 43,3 & 23,3 & 6,7 & 0 & 100 \\
\hline & & Tempat Kafe Instamie Bandung sangat nyaman & 10 & 50 & 40 & 0 & 0 & 100 \\
\hline \multirow[t]{2}{*}{4} & Promosi & $\begin{array}{l}\text { Media promosi (brosur, baligho, media sosial) Kafe Instamie Bandung } \\
\text { sangat menarik }\end{array}$ & 26,7 & 40 & 23,3 & 6,7 & 3,3 & 100 \\
\hline & & Informasi/pesan tentang Kafe Instamie Bandung sangat menarik perhatian anda & 16,7 & 46,7 & 23,3 & 6,7 & 6,7 & 100 \\
\hline \multirow[t]{2}{*}{5} & Orang & Pelayan Kafe Instamie Bandung sangat ramah & 10 & 43,3 & 30 & 10 & 6,7 & 100 \\
\hline & & Pelayan sangat cepat tanggap terhadap keluhan konsumen & 13,3 & 46,7 & 30 & 6,7 & 3,3 & 100 \\
\hline \multirow[t]{2}{*}{6} & Proses & Proses pemesanan sampai penyajian sangat cepat & 16,7 & 33,3 & 33,3 & 16,7 & 0 & 100 \\
\hline & & Penyajian makanan sangat sesuai dengan gambar di buku menu & 6,7 & 46,7 & 36,6 & 6,7 & 3,3 & 100 \\
\hline \multirow[t]{3}{*}{7} & Fasilitas & Tempat parkir di Kafe Instamie Bandung sangat luas & 10 & 26,7 & 40 & 16,7 & 6,7 & 100 \\
\hline & Fisik & Desain interior Kafe Instamie Bandung sangat menarik & 20 & 33,3 & 30 & 16,7 & 0 & 100 \\
\hline & & Tempat duduk di Kafe Instamie Bandung sangat mencukupi & 16,7 & 43,3 & 30 & 10 & 0 & 100 \\
\hline
\end{tabular}

Sumber : survey pendahuluan

30 responden untuk mengetahui faktor dominan apa saja yang mempengaruhi ketidakpuasan konsumen terhadap Kafe Instamie Bandung. Hasil penelitian pendahuluan yang dilakukan kepada konsumen Kafe Instamie Bandung ditunjukkan pada Tabel 7.

Berdasarkan Tabel 7, faktor dominan pertama yang mempengaruhi kepuasan konsumen yaitu harga. Berdasarkan hasil penelitian pendahuluan sebanyak 33,3 \% konsumen Kafe Instamie Bandung menyatakan setuju bahwa harga yang ditawarkan oleh Kafe Instamie Bandung sangat terjangkau atau tidak mahal. Sedangkan sebanyak $66,7 \%$, menyatakan tidak setuju yang berarti bahwa harga yang ditawarkan Kafe Instamie Bandung relatif mahal atau tidak terjangkau. Berdasarkan data tersebut dapat diartikan bahwa harga yang mahal namun tidak sesuai dengan kualitas atau manfaat yang diterima menjadi salah satu faktor yang mempengaruhi rendahnya kepuasan konsumen pada Kafe Instamie Bandung.

Harga merupakan satu-satunya unsur bauran pemasaran yang memberikan pemasukan atau pendapatan bagi perusahaan. Syarat yang harus dipenuhi oleh suatu perusahaan agar dapat sukses dalam persaingan adalah berusaha mencapai tujuan untuk menciptakan dan mempertahankan pelanggan. Agar tujuan tersebut tercapai, maka perusahaan harus mampu menetapkan harga yang tepat dan pantas pada produk atau jasa yang dijualnya. Harga seringkali dianggap sebagai gambaran dari kualitas suatu barang atau jasa. Harga mempunyai pengaruh yang kuat terhadap kepuasan konsumen yang menyebabkan jumlah pengunjung dan pendapatan Kafe Instamie mengalami penurunan. Hal ini diperkuat dengan penelitian yang dilakukan oleh Dwi Candra Pertiwi dan Tri Sudarwanto (2013) yang menyatakan bahwa harga mempunyai pengaruh yang signifikan terhadap kepuasan konsumen.

Faktor dominan kedua yang mempengaruhi kepuasan konsumen terhadap Kafe Instamie Bandung yaitu fasilitas fisik. Berdasarkan hasil peneltian pendahuluan yang dilakukan oleh penulis kepada 30 responden. Sebanyak 36,7\% menyatakan setuju bahwa fasilitas fisik di Kafe Instamie sangat baik dan memadai. Sedangkan sebanyak $63,3 \%$, menyatakan tidak setuju. Berdasarkan hasil penelitian pendahuluan yang telah dilakukan, maka penulis dapat menyimpulkan bahwa fasilitas fisik yang tidak memadai menjadi salah satu faktor yang mempengaruhi rendahnya kepuasan konsumen pada Kafe Instamie Bandung.

Fasilitas fisik merupakan faktor yang sangat utama yang harus menjadi perhatian dari setiap perusahaaan yang bergerak di dalam bidang jasa dimana fasilitas fisik menjadi penunjang dan sarana dalam memberikan pelayanan yang baik kepada para pelanggaan dengan tujuan untuk menciptakan kepuasan bagi konsumen. Proses pelayanan yang baik kepada konsumen akan membentuk persepsi yang baik terhadap perusahaan itu sendiri, sebaliknya jika proses pelayanan yang diberikan tidak baik maka konsumen akan mempunyai persepsi yang tidak baik terhadap perusahaan penyedia jasa tersebut. Hal ini tentu akan merugikan perusahaan, proses pelayanan yang dipersepsikan tidak baik akan menciptakan konsumen yang tidak puas dan berpindah 
ke perusahaan lain. Proses mempunyai pengaruh yang kuat terhadap kepuasan konsumen yang menyebabkan jumlah pengunjung dan pendapatan Kafe Instamie mengalami penurunan. Hal ini diperkuat dengan penelitian yang dilakukan oleh Jimmy Sugiyanto (2013) yang menyatakan bahwa proses mempunyai pengaruh yang signifikan terhadap kepuasan konsumen.

Hasil penelitian pendahuluan di kafe Instamie tentang harga dan proses jasa menunjukkan kurang baik dan konsumen kurang puas. Berdasarkan latar belakang penelitian, penulis mengidentifikasikan pokok pembahasan pada masalah: (1) Bagaimana tanggapan konsumen tentang harga pada Kafe Instamie; (2) Bagaimana tanggapan konsumen tentang proses pada Kafe Instamie; (3) Bagaimana tanggapan konsumen tentang kepuasan pada Kafe Instamie; (4) Seberapa besar pengaruh harga dan proses terhadap kepuasan konsumen Kafe Instamie baik secara simultan maupun parsial.

Harga menjadi salah satu elemen yang paling penting dalam menentukan pangsa pasar dan keuntungan suatu perusahaan. Harga merapakan satusatunya unsur bauran pemasaran yang menimbulkan pemasukan atau pendapatan bagi perusahaan, sedangkan ketiga unsur bauran pemasaran yang lainnya (produk, distribusi, dan promosi) menyebabkan timbulnya biaya (pengeluaran). Disamping itu harga merupakan unsur bauran pemasaran yang bersifat fleksibel, artinya dapat diubah dengan cepat. Kotler \& Amstrong (2014:313) mendefinisikan bahwa Price the amount of money charged for a product or service, or the sum of the value that customers exchange for the benefits or having or using the product or service. (harga merupakan sejumlah uang yang dikeluarkan untuk sebuah produk atau jasa, atau sejumlah nilai yang ditukarkan oleh konsumen untuk memperoleh manfaat atau kepemilikan atau penggunaan atas sebuah produk atau jasa). Menurut Effendi M. Guntur (2010:281) harga adalah sejumlah uang yang ditagihkan atas suatu produk dan jasa atau jumlah dari nilai yang ditukarkan para pelanggan untuk memperoleh manfaat dari memiliki atau menggunakan suatu produk atas jasa. harga merupakan satu-satunya unsur bauran pemasaran yang memberikan pendapatan atau pemasukan bagi perusahaan serta bersifat fleksibel.

Berdasarkan pendapat tersebut, penulis sampai pada pemahaman bahwa harga merupakan sejumlah uang yang ditukarkan untuk sebuah produk atau jasa. Lebih jauh lagi, harga adalah sejumlah nilai yang konsumen tukarkan untuk sejumlah manfaat dengan memiliki atau menggunakan suatu produk atau jasa. pemasar didalam sebuah perusahaan harus benar-benar menetapkan harga yang tepat dan pantas bagi produk atau jasa yang ditawarkan karena menetapkan harga yang tepat merupakan kunci untuk menciptakan dan menangkap nilai pelanggan. Alasan ekonomis akan menunjukan bahwa harga yang rendah atau yang selalu berkompetensi merupakan salah satu pemicu penting untuk meningkatkan kinerja pemasaran, tetapi alasan psikologis dapat menunjukan bahwa harga merupakan indikator kualitas dan karena itu dirancang sebagai salah satu instrumen penjualan sekaligus sebagai alat kompetensi yang menentukan. Harga yang ditetapkan pada dasarnya sesuai dengan yang menjadi pengharapan produsen. Harga juga biasanya mencerminkan kualitas dari produk yang menyertainya, mencerminkan prestis dan sebagainya.

Secara umum, penetapan harga betujuan untuk mencari laba agar perusahaan dapat berjalan namun dalam kondisi persaingan yang semakin ketat tujuan mencari laba maksimal dalam praktisnya akan sulit dicapai. Menurut Kotler dan Keller (2016:491), terdapat beberapa tujuan penetapan harga, antara lain: (1) Kemampuan bertahan (survival); (2) Laba maksimum saat ini (maximum current profit); (3) Pangsa pasar maksimum; (4) Pemerahan pasar maksimum; (5) Kepemimpinan kualitas produk (product-quality leadership); (6) Tujuan-tujuan lainnya (other obejctives).

Menurut Kotler dan Amstrong (2014:313) terdapat beberapa metode yang dapat digunakan untuk menetapkan suatu harga, antara lain: (1) Penetapan harga berdasarkan nilai; (2) Penetapan harga berdasarkan biaya (cost-based pricing); (3) Penetapan harga berdasarkan pesaing (competition-based pricing).

Seluruh aktivitas adalah sebuah proses, dimulai dari proses melibatkan prosedur-prosedur, tugas-tugas, jadwal-jadwal, mekanisme-mekanisme, rutinitasrutinitas dengan produk jasa yang disalurkan kepada konsumen. Berikut definisi proses menurut para ahli. Menurut Kotler dan Keller (2016:48) mengemukakan bahwa proses refflect all the creativity, discipline, and structure brought to marketing management (proses merupakan mencerminkan semua kreatifitas, disiplin dan struktur yang ada didalam manajem pemasaran). Sedangkan menurut Zeithaml dan Bitner yang dikutip oleh Hurriyati, Ratih (2010:64) menyatakan bahwa proses adalah semua prosedur aktual, mekanisme dan aliran aktivitas yang digunakan untuk menyampaikan jasa.

Menurut Tjiptono (2012:146) prosess adalah Proses menyangkut dari cara kerja perusahaan dalam memberikan pelayanan kepada konsumen dalam penyediaan hidangan. Proses kerja ini diawali dari konsumen masuk hingga keluar dari perusahaan. Proses kerja ini menyangkut dari kecepatan kerja dan kemudahan serta rasa aman. Jika proses itu cepat dilakukan maka konsumen akan terpuaskan.

Berdasarkan definisi para ahli tersebut, penulis sampai pada pemahaman bahwa proses merupakan seluruh aktivitas maupun kegiatan yang dilakukan oleh suatu perusahaan dalam menyampaikan jasa kepada konsumen. Proses dapat dibedakan menjadi dua cara diantaranya, sebagai berikut: (1) Complexity, hal ini berhubungan dengan langkah-langkah dan tahapan yang dilalui dalam proses. (2) Divergence, berhubungan 
dengan adanya perubahan dalam langkah ataupun tahapan yang dilalui dalam proses.

Sehubungan dengan dua cara tersebut terdapat empat pilihan yang dapat dipilih oleh marketer yaitu: (a) Reduced/Divergence, dalam hal ini berarti terjadi pengurangan biaya, peningkatan produktivitas dan kemudian distribusi; (b) Increased Divergence, dalam hal ini berarti memperbanyak customisasi dan fleksibilitas dalam produksi yang dapat menimbulkan naiknya harga; (c) Reduced Complecity, dalam hal ini berarti cenderung lebih terspesialisasi; (d) Increased Complecity, dalam hal ini berarti lebih cenderung ke penetrasi pasar dengan cara menambahkan servis yang diberikan.

Pada umumnya perusahaan melakukan aktivitas bisnis atau tugas pemasar adalah untuk mengkomunikasikan dan menawarkan produk atau jasa dari suatu perusahaannya dengan tujuan untuk menciptakan sebuah kepuasan bagii konsumennya.

Menurut Kotler \& Keller (2016 : 153), in general: Satisfaction is a person's feelings of pleasure or disappointment that result from comparing a product or service's perceived performance (or outcome) to expectations. (kepuasan merupakan perasaan senang atau kecewa seseorang sebagai hasil dari perbandingan sebuah kinerja produk atau jasa dengan ekspektasinya.

Popo Suryana dan Rissa Bela (2015) dalam penelitiannya menyimpulkan bahwa kepuasan konsumen dipengaruhi oleh kualitas produk dan citra merek. Artinya banyak variabel dan faktor yang mempengaruhi kepuasan konsumen dalam memenuhi kebutuhan dan keinginannya.

Fandy Tjiptono (2012:298) menyatakan bahwa kepuasan konsumen didasarkan pada tiga teori utama yaitu: (1) Contrast Theory berasumsi bahwa konsumen akan membandingkan kinerja produk aktual dengan ekspektasi pra-pembelian. Apabila kinerja aktual lebih tinggi dari ekspektasi, maka monsumen akan merasa puas. Sebaliknya apabila kinerja aktual lebih rendah dibandingkan dengan ekspektasi konsumen, maka konsumen akan tidak puas; (2) Assimilation Theory berasumsi bahwa evaluasi purna beli merupakan fungsi positif dari ekspektasi konsumen pra-pembelian. Karena proses diskonfirmasi secara fsikologis tidak enak dilakukan, konsumen cenderung secara perseptual mendistori perbedaan antara ekspektasi dan kinerjanya kearah ekspektasi awal. Dengan kata lain penyimpangan dari ekspektasinya cenderung akan diterima oleh konsumen yang bersangkutan; (3) Assimilation Contrast Theory berpegangan bahwa terjadinya efekasimilasi (assimilation effect) atau efek kontras (contras effect) merupakan funsi dari tingkat kesenjangan antara kinerja yang diharapkan dengan kinerja aktual. Apabila kesenjangan besar, maka konsumen akan memperbesar gap tersebut sehingga produk dipersepsikan jauh lebih baik atau lebih buruk dibandingkan dengan kenyataannya (sebagaimana halnya contrast theory).
Namun jika kesenjangan tidak terlalu besar, assimilation theory yang berlaku.

Untuk mencapai kepuasan, perusahaan harus mengetahui faktor apa saja yang mempengaruhi kepuasan bagi konsumen itu sendiri. Menurut Kotler dan Keller (2016:156) menyatakan bahwa ada beberapa faktor yang mempengaruhi kepuasan konsumen, antara lain: (1) Kualitas produk, pelanggan akan merasa puas bila hasil evaluasi mereka menunjukkan bahwa produk yang mereka gunakan berkualitas; (2) Kualitas pelayanan (service quality), pelanggan akan merasa puas jika mereka mendapatkan pelayanan yang baik atau sesuai dengan harapannya; (3) Harga, produk dengan kualitas yang sama tetapi menetapkan harga yang relatif murah akan memberi nilai yang tinggi kepada pelanggannya; (4) Faktor emosional (emotional factor), pelanggan akan merasa bangga dan mendapatkan keyakinan bahwa orang lain kagum kepadanya bila mengunakan produk merek tertentu; (5) Biaya dan kemudahan, pelanggan yang tidak perlu mengeluarkan biaya tambahan atau membuang waktu untuk mendapatkan suatu produk, cenderung puas terhadap produk.

Menurut Kotler dan Keller (2016:155) pada umumnya pelanggan yang sangat puas dapat dilihat dengan ciri-ciri sebagai berikut: (1) Stay loyal longer, (tetap setia); (2) Buy more as the company introduces new and upgraded products, (membeli lebih banyak pada produk baru perusahaan); (3) Talks favorably to others about the company and its products, (berbicara yang menguntungkan kepada orang lain tentang produk dan perusahaan); (4) Pay less attention to competing brands and is less sensitive to price, (kurang memperhatikan merek pesaing dan kurang sensitive terhadap harga); (5) Offer product or service ideas to the company, (menawarkan ide untuk produk atau jasa kepada perusahaan); (6) Cost less to serve than new customers because transactions can become routine, (mengurangi biaya untuk konsumen baru karena transaksinya dapat menjadi rutinitas).

Kepuasan pelanggan terbagi ke dalam lima tingkat atau level dimulai dengan pelanggan merasa tidak puas hingga pelanggan merasa berada pada tingkat sangat puas, menurut Kotler dan Keller (2016:155) yaitu: (1) At level one, customer are likely abandon the company and even bad-mouth. (Level pertama, pelanggan yang mungkin akan meninggalkan perusahaan dan bahkan menjelek-jelekan); (2) At level two to level four, customer are fairly satisfied but still find it easy to swich when better offer comes along. (Pada level kedua sampai level kelima, pelanggan cukup puas tetapi masih merasa mudah untuk beralih ketika tawaran yang lebih baik datang); (3) At level five, the customer is very likely to repurchase and even spread good word of mouth about the company. (Pada level kelima, pelanggan sangat mungkin untuk membeli kembali dan bahkan menyebarkan berita baik dari mulut ke mulut tentang perusahaan). 
Terdapat beberapa metode yang dapat digunakan oleh suatu perusahaan dalam mengukur kepuasan konsumen. Menurut Fandy Tjiptono (2012:314) mengemukakan empat metode untuk mengukur kepuasan pelanggan, yaitu: (1) Sistem keluhan dan saran; (2) Mhystery shopper (pembeli misterius); (3) Loss customer analysis; (4) Survei kepuasan konsumen (periodic survey).

Staus dan Neuhauss yang dikutip oleh Tjiptono (2012:204) membedakan tipe-tipe kepuasan dan ketidakpuasan konsumen berdasarkan kombinasi antara emosi-emosi spesifik terhadap penyedia jasa, ekspektasi menyangkut kapabilitas kinerja masa depan pemasok jasa, dan minat berperilaku untuk memilih lagi penyedia jasa bersangkutan: (1) Demanding customer satisfaction; (2) Stable customer satisfaction; (3) Resigned customer satisfaction; (4) Stable customer dissatisfaction; (5) Demanding customer dissatisfaction.

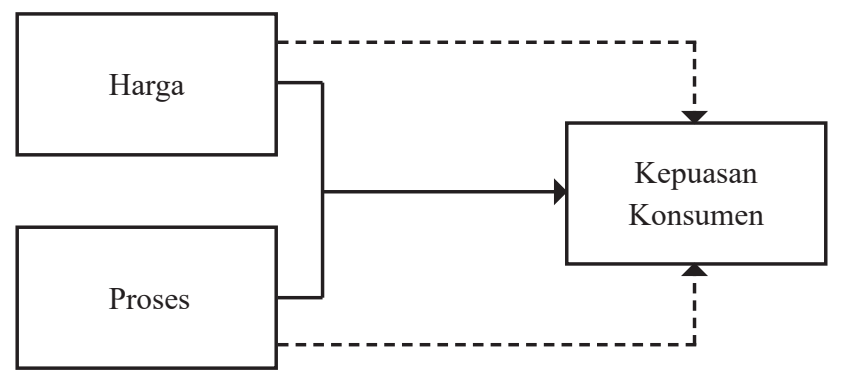

Gambar 1. Kerangka Pemikiran

\section{METODE}

Pada penelitian ini yang menjadi populasi adalah konsumen yang melakukan kunjungan ke Kafe Instamie, yaitu 3.228 orang selama 9 bulan terakhir, maka dari data tersebut didapatkan ukuran sampel dengan rumus Slovin sebagai berikut :

Teknik pengumpulan data yang digunakan adalah penelitian lapangan dan studi kepustakan. Pengujian data yang digunakan dalam penelitian ini yaitu uji validitas uji reliabilitas. Metode Analisis yang digunakan adalah analisis regresi linier berganda, analisis korelasi berganda, dan analisis koefisien determinasi simultan, dan parsial.

\section{HASIL DAN PEMBAHASAN}

Harga merupakan salah satu hal yang sering menjadi pertimbangan konsumen untuk melakukan pembelian. Penentuan atau penetapan harga harus diikuti dengan kualitas produk dan manfaatnya sehingga mampu mempengaruhi konsumennya. Dilihat dari empat dimensi harga yang terdiri dari keterjangkauan harga, kesesuaian harga dengan kualitas produk, daya saing harga dan kesesuaian harga dengan manfaat menunjukan bahwa harga yang ditetapkan di Kafe
Instamie dikategorikan kurang terjangkau dengan nilai rata-rata sebesar 3,13. Beberapa indikator dengan skor di bawah rata-rata yaitu (1) keterjangkauan harga dengan skor rata-rata sebesar 3,11. (2) perbandingan harga dengan pesaing dengan skor rata-rata sebesar 3,10 dan (3) potongan harga yang ditawarkan dengan skor rata-rata sebesar 2,82. Indikator yang berada di bawah rata-rata tersebut dikatakan wajar mengingat sebagian besar karakteristik responden yang mayoritas memiliki pendapatan $<$ Rp. 2.000.000,- dengan status pelajar/ mahasiswa sehingga mereka menyatakan harga kurang terjangkau karena penghasilan mereka masih berasal dari orangtua. Hal ini menyebabkan konsumen dengan status pelajar/mahasiswa harus pandai-pandai mengatur keuangannya.

Berdasarkan hasil penelitian deskriptif tabulasi data konsumen Kafe Instamie mengenai proses pelayanan dengan tiga dimensi proses pelayanan yang terdiri dari pelayanan, kemudahan dan keamanan menunjukkan bahwa proses pelayanan yang dilakukan di Kafe Instamie dikategorikan kurang baik dengan nilai ratarata sebesar 3,20. Beberapa indikator dengan skor di bawah rata-rata yaitu keramahan pelayan saat melayani konsumen, kecepatan penyajian produk yang dipesan, dan keamanan tempat parkir yang disediakan. Nilai rata-rata terendah berada pada indikator kemanan tempat parkir yang disediakan, karena tidak adanya juru parkir untuk menjaga kendaraan-kendaraan konsumen sehingga konsumen merasa kurang nyaman pada saat menikmati makanan dan minuman karena merasa ketakutan kendaraan konsumen hilang atau dicuri. Indikator yang berada di bawah skor rata-rata tersebut dikatakan wajar mengingat sebagian besar karakteristik responden mayoritas adalah wanita. Wanita seringkali lebih sensitif dan ekspresif, menuntut pelayanan yang lebih baik sesuai dengan biaya yang dikeluarkannya, selain itu cenderung tidak sabaran dan mempunyai rasa ketakutan yang lebih besar.

Berdasarkan hasil penelitian deskriptif tabulasi data konsumen Kafe Instamie mengenai kepuasan dengan dua dimensi kepuasan yang terdiri dari kinerja dan harapan dikategorikan kurang puas dengan nilai ratarata sebesar 3,14. Terdapat beberapa indikator dengan skor di bawah rata-rata yaitu kinerja proses pelayanan, dan harapan konsumen atas proses pelayanan. Hal tersebut terjadi karena proses pelayanan di Kafe Instamie kurang cepat seperti penyajian makanan dan minuman yang dianggap lama dan tempat parkir yang dirasa tidak aman menurut konsumennya.

Berdasarkan perhitungan dan analisis regresi linear berganda dapat diketahui bahwa harga dan proses pelayanan memiliki pengaruh signifikan terhadap kepuasan konsumen pada Kafe Instamie. Berdasarkan analisis korelasi berganda didapatkan hubungan yang kuat antara harga dan proses pelayanan terhadap kepuasan konsumen dengan angka sebesar 0,767. Berdasarkan analisis koefisien determinasi diketahui 
bahwa harga dan proses pelayanan memiliki kontribusi pengaruh terhadap kepuasan konsumen sebesar 58,8\%. Hal ini didukung dengan hasil penelitian yang dilakukan oleh Endah Lisarini dan Ningtyas (2014) dan Melda Lumbantobing (2013) yang menyatakan bahwa bauran pemasaran 7P yang teridiri dari produk, harga, tempat, promosi, orang, proses pelayanan dan fasilitas fisik secara bersama-sama dan parsial berpengaruh terhadap kepuasan konsumen.

Berdasarkan hasil pengujian koefisien determinasi secara parsial menunjukkan persentase pengaruh harga terhadap kepuasan konsumen sebesar 23\%. Hal ini mengindikasikan bahwa harga memiliki peran untuk mempengaruhi kepuasan konsumen. Artinya apabila harga yang ditawarkan Kafe Instamie semakin terjangkau, kompetitif dan sering melakukan potongan harga serta sesuai dengan harapan konsumen maka kepuasan konsumen akan mengalami peningkatan. Dengan demikian, penulis menyatakan sikap setuju bahwa harga berpengaruh terhadap kepuasan konsumen. Pengaruh harga terhadap kepuasan konsumen tersebut sejalan dengan penelitian yang dilakukan oleh Johanes Gerardo Runtunuwu, Sem Oroh dan Rita Taroreh (2014), yang menyatakan bahwa kualitas produk, harga dan kualitas pelayanan berpengaruh signifikan terhadap kepuasan konsumen baik secara simultan maupun parsial. Penelitian lain yang sesuai juga diungkapkan oleh Jimmy Sugianto dan Sugiharto (2013), yang menyatakan bahwa service quality, food quality, dan price berpengaruh signifikan terhadap kepuasan konsumen baik secara simultan maupun parsial.

Berdasarkan hasil pengujian koefisien determinasi secara parsial menunjukkan persentase pengaruh proses pelayanan terhadap kepuasan konsumen sebesar 35,8\%. Hal ini mengindikasikan bahwa proses pelayanan memiliki pengaruh yang lebih besar bila dibandingkan dengan harga dalam mempengaruhi kepuasan konsumen. Hal ini sangatlah wajar mengingat konsumen yang melakukan pembelian di Kafe Instamie mayoritas adalah wanita yang sangat peka terhadap pelayanan yang diterimanya. Artinya apabila proses pelayanan yang dilakukan Kafe Instamie semakin baik, dengan pelayanan yang semakin cepat, keramahan pelayan yang semakin baik dan keamanan yang semakin ditingkatkan maka kepuasan konsumen akan mengalami peningkatan. Pengaruh proses pelayanan terhadap kepuasan konsumen tersebut sejalan dengan penelitian yang dilakukan oleh Rizka Khoirur Rohmah (2013), yang menyatakakan bahwa bauran pemasaran yang teridiri dari produk, harga, tempat, promosi, orang, proses pelayanan dan sarana fisik berpengaruh baik secara simultan maupun parsial terhadap kepuasan konsumen. Penelitian lain yang sesuai juga diungkapkan Noviana (2013) bahwa marketing mix yang terdiri dari produk, harga, tempat, promosi, orang, proses dan fasilitas fisik berpengaruh signifkan terhadap kepuasan konsumen baik secara simultan maupun parsial.

\section{KESIMPULAN}

Berdasarkan hasil penelitian dapat diambil kesimpulan: (1) Harga pada Kafe Instamie dinilai kurang terjangkau menurut konsumen. Harga mendapat penilaian rendah pada indikator harga produk yang ditawarkan, perbandingan harga dengan pesaing dan indikator potongan harga (diskon) yang ditawarkan, sedangkan indikator tertinggi pada harga sesuai dengan minat beli konsumen; (2) Proses pelayanan pada Kafe Instamie dinilai kurang baik menurut konsumen pada dimensi proses pelayanan seperti pelayanan, kemudahan dan keamanan, keramahan pelayan, kecepatan penyajian produk dan indikator keamanan tempat parkir. Sedangkan indikator tertinggi pada kemudahan dalam melakukan pembayaran; (3) Kepuasan konsumen Kafe Instamie dinilai kurang puas terhadap dimensi kinerja dan harapan. Kepuasan konsumen masih terdapat penilaian rendah pada indikator kinerja proses pelayanan dan harapan atas proses pelayanan yang dilakukan. Indikator tertinggi pada kinerja harga yang ditawarkan Kafe Instamie; (4) Harga dan proses pelayanan berpengaruh terhadap kepuasan konsumen. Proses pelayanan memiliki pengaruh paling dominan terhadap kepuasan konsumen dan harga memiliki pengaruh paling kecil.

\section{DAFTAR PUSTAKA}

Effendi M. Guntur, 2010. Transformasi Manajemen Pemasaran Membangun Citra Negara, Sagung Seto, Jakarta.

Endah \& Ningtyas. 2014. Pengaruh Bauran Pemasaran 7P Terhadap Kepuasan Pelanggan di Sweetberry Argowisata Cipanas, Jurnal Agrosience, Volume 4, No 2.

Fandy Tjiptono, 2012. Service, Quality, \& Satisfaction. Andi Offset, Yogyakarta.

Hurriyati, R. 2010. Manajemen Pemasaran Jasa Dan Bauran Pemasaran. Alfabeta. Jakarta.

Jimmi Sugiyanto. 2013. Service Quality, Food Quality dan Price Terhadap Kepuasan Pelanggan Yung Ho Surabaya, Jurnal Manajemen Pemasaran Petra, Vol 1 No 2., 1-10.

Kotler, Philip and Amstrong, Gary. 2014, Principles Of Marketing, (15th Edition), Pearson Prentice Hall, New Jersey.

Kotler, Philip \& keller, kevin Lane. 2016. Marketing Management, 16thEdition, Pearson Prentice Hall Published, New Jersey.

Melda M. Lumbantobing. 2013. Pengaruh Prestise, Persaingan dan Bauran Pemasaran 7P Terhadap Kepuasan Pelanggan Fountain Ice Cream Caffe Plaza Medan Fair. Jurnal Media Informasi Manajemen, Volume 1, No 1.

Noviana, B. I. 2013. Pengaruh Service Marketing Mix Terhadap Kepuasan Konsumen Hotel Amaris 
Surabaya. Jurnal Hospitality dan Manajemen Jasa, 1(2), 472-482.

Pertiwi, D. C., \& Sudarwanto, T. 2014. Pengaruh Kualitas Layanan dan Harga Terhadap Kepuasan Konsumen (Studi Pada Konsumen Coffee Corner Surabaya). Jurnal Pendidikan Tata Niaga. Surabaya: Universitas Negeri Surabaya.

Popo Suryana dan Risa Bela. 2015. Pengaruh Kualitas Produk dan Citra Merek Terhadap Kepuasan dan Implikasinya pada Loyalitas Pelanggan (Survei Pada Konsumen Smartphon), Jurnal Riset Bisnis dan Management (JRBM), Vol. 1 No 1, Februari 2015, Hal. 43-51

Rizka Hoirur Rohmah. 2013. Pengaruh Bauran Pemasaran Terhadap Kepuasan Konsumen Pada Coffe Corner Surabaya, Jurnal Ilmu dan Riset
Manajemen, Volume 2, No 10.

Runtunuwu, J. G., Oroh, S., \& Taroreh, R. 2014. Pengaruh Kualitas Produk, Harga, Dan Kualitas Pelayanan Terhadap Kepuasan Pengguna Cafe Dan Resto Cabana Manado. Jurnal EMBA: Jurnal Riset Ekonomi, Manajemen, Bisnis dan Akuntansi, 2(3).

www. Bandungkota.bps.go.id, diakses Oktober 2016 www.hukumonline.com/pusatdata/detail/ 1t4dc76ad5d3070/node/1t51e5384842a9b/ peraturan-menteri-kebudayaan-dan-pariwisatano-pm.87_hk.501_mkp_2010-tahun-2010-tatacara-pendaftaran-usaha-jasa-makanan-danminuman

www. perpustakaan.bappenas.go.id, diakses Oktober 2016 